\title{
Ecological importance of passive deposition of organic matter into burrows of the SW Atlantic crab Chasmagnathus granulatus
}

\author{
Florencia Botto ${ }^{1,2, *}$, Oscar Iribarne ${ }^{1,2}$, Jorge Gutierrez ${ }^{1,2}$, José Bava ${ }^{2,3}$, \\ Antonio Gagliardini ${ }^{2,3}$, Ivan Valiela ${ }^{4}$ \\ ${ }^{1}$ Departamento de Biología (FCEyN), Universidad Nacional de Mar del Plata, CC 573 Correo Central, 7600 Mar del Plata, \\ Argentina \\ ${ }^{2}$ Consejo Nacional de Investigaciones Científicas y Técnicas (CONICET), Rivadavia 1917, 1033 Buenos Aires, Argentina \\ ${ }^{3}$ Instituto de Astronomía y Física del Espacio, CC 67, sucursal 28, 1428 Buenos Aires, Argentina \\ ${ }^{4}$ Boston University Marine Program, Marine Biological Laboratory, 7 MBL Street, Woods Hole, 02543 Massachusetts, USA
}

\begin{abstract}
The burrowing crab Chasmagnathus granulatus is the most abundant bioturbator in estuarine intertidal sediments from southern Brazil to central Argentina. This crab is a deposit feeder that excavates and maintains large semi-permanent open burrows with funnel shaped entrances. In this study we showed that the funnel shaped burrows with low aspect ratio are the most common and, with field experiments, we demonstrated that these burrows are also the most efficient in the capture of organic matter. As shown by C isotopic signatures, the origin of trapped detrital material is Spartina densiflora. Burrows are distributed in the upper part of estuaries and saltmarshes, mostly in areas of low energy, and cover extensive areas between the marsh vegetation and the open estuary. Through sampling of crab densities and use of satellite images, we estimated the number of burrows of different shapes in the Bahia Blanca estuary $\left(38^{\circ} 50^{\prime} \mathrm{S}\right)$, one of the largest estuarine intertidals in the SW Atlantic. After combining this information with the trapping efficiency of burrows of different shapes, we estimated that within $100 \mathrm{~d}$, a crab bed could capture the entire annual production from a marsh area of similar size. Therefore, we suggest that these extensive burrow beds may be considered large macrodetritus retention areas, reducing the amount of organic matter exported from marshes but locally increasing the sediment organic matter content.
\end{abstract}

KEY WORDS: Spartina-marsh $\cdot$ Chasmagnathus granulatus $\cdot$ Burrowing $\cdot$ Detritus dynamics Resale or republication not permitted without written consent of the publisher

\section{INTRODUCTION}

Organic detritus (sensu Mann 1972) is a major component of estuarine sediments, and one of the most important food sources in estuaries and in the coastal ocean. High fish production has been related to high concentrations of organic detritus, and a major part of energy flow in most estuaries is via the detrital pathway (e.g. Day et al. 1989). Although its importance has been challenged, the classical detritus food web paradigm can still be supported as a significant advancement in the understanding of how several estuaries work (Day et al. 1989). Intertidal marshes are often net exporters of organic matter in the form of detritus and animals (Teal 1962, Valiela \& Teal 1979, Deegan \& Garritt 1997). In some estuaries there is a significant export of material from salt marshes to neighboring ecosystems (Valiela \& Teal 1979, Valiela et al. 2000). In other cases, most of the detritus is exported only to the adjacent sediment accumulating basin (Nixon 1980, Long \& Mason 1983).

The export of organic matter from saltmarshes can be by bedload and nearbed detritus transport, by tidal fluxes (Hemminga et al. 1996), or by animals (fishes 
and birds) feeding in the marsh ecosystem (Deegan \& Garrit 1997). The export characteristics of any particular marsh primarily depend on factors such as vegetation type, physiography, and geomorphology (Taylor \& Allanson 1995). However, invertebrates can also affect the amount and fate of detrital material (e.g. Teal 1962, Smallwood et al. 1999). For instance, they can feed on detritus or can increase detritus production due to their feeding activities. Burrowing organisms may have additional significance in the detritus pathway by enhancing decomposition of organic matter via bioturbation and irrigation (Aller \& Aller 1986). Burrows work as passive traps of bedload-transported sediment and detritus in deep-sea (Aller \& Aller 1986) and intertidal sediments (Botto \& Iribarne 2000). Burrows of seagrass/algae harvesters such as Thalassinidean shrimps, which collect drifting detrital plant material, are likely to act as significant nutrient 'sinks' in shallow, near shore environments (Suchanek 1985). While it is well known that some crabs reduce carbon and nutrient exports from mangrove forests by actively burying litter within their burrows (Robertson 1986, Twilley et al. 1997), it is not understood how the passive deposition of detritus into crab burrows can affect the export of organic mater from salt marshes to coastal environments.

Intertidal sediments of estuaries and embayments in the SW Atlantic (southern Brazil to central Argentina) are dominated by the burrowing grapsid crab Chasmagnathus granulatus (Boschi 1964, Spivak et al. 1994, Iribarne et al. 1997). This crab inhabits soft bare sediment flats and salt marshes dominated by species of Spartina and Sarcocornia (Spivak et al. 1994, Iribarne et al. 1997, Bortolus \& Iribarne 1999, 2000) at densities that can be as high as 60 crabs m$^{-2}$ (Iribarne et al. 1997, Bortolus \& Iribarne 1999). Crabs excavate and maintain semipermanent open burrows (Spivak et al. 1994, Iribarne et al. 1997) that differ in shape depending on the habitat. In salt marshes, where crabs are primarily herbivorous, burrows are straight tunnels (entrance diameter up to $10 \mathrm{~cm}$ ) that extend up to $1 \mathrm{~m}$ depth (Iribarne et al. 1997, Bortolus \& Iribarne 1999, Bortolus et al. 2002, Botto et al. 2005). In mud flats, tidal creeks, and channels, where crabs are mainly deposit feeders, burrows are shallow (up to $30 \mathrm{~cm}$ depth) and with funnel-shaped entrances (diameter up to $20 \mathrm{~cm}$; Iribarne et al. 1997, Botto \& Iribarne 2000, Botto et al. 2005). Differences in burrow shape can be due to differences in structural limitations of sediments that support a type of burrow. However, based on the heuristic model proposed by Suchanek (1985), the architecture of $C$. granulatus burrows reflects variations in trophic modes associated with sediment structure (Iribarne et al. 1997). According to this model, burrows with funnel shape entrances favor deposit feeding because they work as sediment traps by enhancing capture of bedload-transported particles that slip down the sides of the funnel (Suchanek 1983, Poore \& Suchanek 1988, Witbaard \& Duineveld 1989, Vaugelas 1990, Nickell \& Atkinson 1995).

The large size of the surface openings relative to funnel depth in Chasmagnathus granulatus burrows on tidal flats is also likely to be related to the passive trapping of surface-deposited detritus. Measurements of particle fluxes through turbulent systems have shown that the collection efficiency of cylindrical traps increases with increasing width/height ratios (Butman 1986, Butman et al. 1986, DePatra \& Levin 1989, Yager et al. 1993). Sediment trap collection can be additionally affected by bed roughness, which enhances turbulence and therefore particle fluxes through cavities (Yager et al. 1993). C. granulatus excavates sediments during its burrow maintenance activities. These sediments are deposited as mounds nearby burrow openings, and significantly contribute to bed roughness, potentially enhancing particle trapping (see Yager et al. 1993). Therefore, C. granulatus burrows occurring on tidal flats could intercept marsh-derived detritus in their pathway to estuarine waters. In fact, funnelshaped burrows of C. granulatus contain sediment with a higher content of organic matter and more abundant meiofaunal organisms than surface tidal flat sediments (Iribarne et al. 1997, Botto \& Iribarne 2000). Here, we propose that the extensive high-density burrow beds of C. granulatus, which form a wide and almost continuous band between marshes and the open estuary, are large macrodetritus retention areas that work as sinks for organic matter that otherwise would be exported to the adjacent coastal system (Iribarne et al. 1997, Botto \& Iribarne 2000). To evaluate this hypothesis we (1) tested the efficiency of different burrow shapes in trapping detritus using field experiments, (2) analyzed natural stable isotopes of $\mathrm{C}$ to identify the origin of organic matter trapped in burrows, and (3) used a combination of field sampling and analysis of satellite images to estimate the density of burrows of different size and shape and their potential for trapping sedimentary organic matter and macro-detritus.

\section{MATERIALS AND METHODS}

The effect of burrow architecture on the trapping of organisms, sediment, and detritus was evaluated in tidal flats of the Mar Chiquita coastal lagoon (Argentina, $37^{\circ} 32^{\prime}$ to $37^{\circ} 45^{\prime} \mathrm{S}, 57^{\circ} 26^{\prime} \mathrm{W}$ ). This site is a body of brackish water (approximately $46 \mathrm{~km}^{2}$ ) affected by low amplitude $(<1 \mathrm{~m})$ tides (i.e. Lanfredi et al. 1987, Spivak et al. 1994) and characterized by mud- 
flats and large surrounding cordgrass marshes (almost monospecific stands of Spartina densiflora) (Iribarne et al. 1997, Bortolus et al. 2002). Current velocities in these tidal flats vary between $0 \mathrm{~cm} \mathrm{~s}^{-1}$ and $15 \mathrm{~cm} \mathrm{~s}^{-1}$ (mean value $\left.5.4 \mathrm{~cm} \mathrm{~s}^{-1}\right)$, with the highest values $(15 \mathrm{~cm}$ $\mathrm{s}^{-1}$ ) lasting only few minutes during spring tide flows (Iribarne \& Botto 1998).

To characterize the shape of the entrance of burrows, we evaluated the relationship between burrow entrance and funnel depth (i.e. the distance between the plane generated by the burrow entrance and the plane generated by the end of the funnel, which is also the beginning of the tunnel). We randomly selected 78 burrows, measured the diameter of the entrance and the funnel depth, and statistically evaluated the relationship between funnel depth and diameter of entrance with correlation analysis (Pearson coefficient; Zar 1999).

To compare sediment characteristics at burrow beds and adjacent areas without burrows, 10 samples were randomly taken at each environment using a PVC core (3 cm diameter, $40 \mathrm{~cm}$ depth). These samples were sectioned in $5 \mathrm{~cm}$ depth layers, and only the top 3 layers were used for subsequent analyses. Grain size frequency distribution was obtained by sieve and pipette methods following Carver (1971). Water content was calculated as the difference between wet and dry weight of the samples after oven-drying at $70^{\circ} \mathrm{C}$ for $72 \mathrm{~h}$. A subsample $(10 \mathrm{~g})$ was then incinerated $\left(550^{\circ} \mathrm{C}\right.$ for $8 \mathrm{~h}$ ) and weighed to obtain percentage of ash free dry weight (AFDW) as a measure of organic matter content.

To evaluate the effect of burrow entrance shape on detritus and sediment trapping under hydrodynamically realistic conditions, we deployed burrow-mimics in non-vegetated tidal flats inhabited by crabs. The burrow mimics had different funnel shapes ( $\mathrm{n}=10$ or more): (1) large aspect ratio funnel shape (funnel depth/entrance diameter $=1.5)$, (2) medium aspect ratio funnel shape (funnel depth/entrance area $=1$ ), (3) low aspect ratio funnel shape (funnel depth/ entrance diameter $=0.5$ ). Entrances of funnel-shaped burrow mimics were all $10 \mathrm{~cm}$ in diameter with funnel depths of $15 \mathrm{~cm}, 10 \mathrm{~cm}$, and $5 \mathrm{~cm}$ respectively (see Fig. 1 for diagrams of burrow mimics). At the end of the funnel, a PVC tube (3 $\mathrm{cm}$ diameter, $30 \mathrm{~cm}$ depth) was inserted to collect trapped material. Burrow mimics were deployed during low tide at the intertidal mudflat and filled with filtered estuarine water to avoid nondesired sedimentation by incoming water. The sediments collected in the mimics were sampled after 2 tidal cycles (i.e. $\sim 24 \mathrm{~h}$ ) and the experiment was repeated on 15 occasions. The idea of this experiment was to maintain the flow characteristics of burrow beds regarding sediment structure, roughness and fluid dynamics, in order to only evaluate the effect of burrow shape on particle trapping.

Material trapped in the mimics was dried at $60^{\circ} \mathrm{C}$ for $4 \mathrm{~d}$ and then weighed. AFDW was obtained from subsamples combusted at $450^{\circ} \mathrm{C}$ for $8 \mathrm{~h}$. The null hypotheses (no differences in the amount of sediment and percentage of AFDW among treatments) were evaluated with Kruskal-Wallis tests for each experimental date (Zar 1999). During each experimental date, sediment traps constructed with PVC pipes (3 cm diameter, $60 \mathrm{~cm}$ depth; following Emerson 1991) were also deployed to measure sediment movement rates. Traps were deployed as burrow mimics and the material collected by them was dried and weighed to estimate rates of bedload sediment transport $\left(\mathrm{g} \mathrm{m}^{-1} \mathrm{~d}^{-1}\right)$.

Macro-detritus was separated from sediments to evaluate its proportion in the trapped material. The material was sieved through a $0.05 \mathrm{~mm}$ mesh screen to discard the fine sediment. Next, the retained material was placed in a glass container with distilled water, and the decanted sediments were discarded (this procedure was repeated until no sediments decanted). Then, the macrodetritus was collected under binocular microscope $(10 \times$ magnification; any plastic debris or remaining sediment was discarded), dried at $60^{\circ} \mathrm{C}$, and weighed. This procedure was performed with 40 randomly selected burrow mimics, and the relationship between the percentage of macrodetritus and the AFDW of trapped material was evaluated with correlation analysis (Pearson coefficient; Zar 1999).

To identify the origin of organic matter accumulated in burrows of Chasmagnathus granulatus and its relationship with consumers, we used stable isotopes of C as natural markers (following Michener \& Schell 1994). The relationship ${ }^{13} \mathrm{C} /{ }^{12} \mathrm{C}$ is a good indicator of the origin of the organic matter in estuarine environments as it gives a different signature if the plant is $\mathrm{C}_{3}$ (i.e. Sarcocornia spp.), $\mathrm{C}_{4}$ (i.e. Spartina spp.), or microalgae. Different signatures between terrestrial plants and algae are a consequence of $\mathrm{C}$ sources (carbon dioxide from the air and carbonates from water, respectively). Moreover, the reutilization of $\mathrm{CO}_{2}$ by $\mathrm{C}_{4}$ plants results in a higher accumulation of ${ }^{13} \mathrm{C}$ in their tissues (Lajtha \& Marshall 1994, Valiela 2000). Signatures of surface sediments and those accumulated in burrows were compared with the signatures of the most important estuarine primary producers in the study area (i.e. microalgae, the macroalgae Ulva lactuca and Spartina densiflora). Benthic microalgae were extracted from sediment samples (10 cm diameter and $2 \mathrm{~cm}$ deep) following Couch (1989). This method was based on algal migration to a light source. The Couch method is designed to permit collection while avoiding contamination with detritus. Before isotopic analysis, we examined the samples microscopically to ensure that they 
were free of detritus. We also obtained crab samples to evaluate their nutritional $\mathrm{C}$ source.

All the samples (animals, plants and sediments) were oven dried $\left(48 \mathrm{~h}\right.$ at $\left.60^{\circ} \mathrm{C}\right)$, ground to a fine powder, weighed, and loaded into tin capsules. Stable isotopes were analyzed by mass spectrophotometry in the Stable Isotope Facility of the University of California at Davis (USA). The stable isotopes ratios were expressed as $\delta$ values as $\%$ : $\delta^{13} \mathrm{C}=\left[R_{\text {sample }}\left(R_{\text {standard }}\right)^{-1}-1\right] \times 1000$, where $R$ is the ratio ${ }^{13} \mathrm{C} /{ }^{12} \mathrm{C}$ of the sample or the standard used (i.e. Vienna Pee Dee Belemnite). Differences in $\delta^{13} \mathrm{C}$ among producers were evaluated with ANOVA, and differences between sediments from burrows and from the surface with $t$-tests (Zar 1999).

Seven LANDSAT 5-TM images, including those of the NW extreme of the Bahía Blanca estuary, (Argentina, $38^{\circ} 50^{\prime}$ to $38^{\circ} 43^{\prime} \mathrm{S}, 62^{\circ} 16^{\prime}$ to $62^{\circ} 27^{\prime} \mathrm{W}$; $21168 \mathrm{ha}$ ) were analyzed to evaluate the proportion of the intertidal area occupied by crabs. The Bahia Blanca estuary is a large ecosystem with low freshwater input and very extensive intertidal flats surrounded by large marshes dominated by Spartina alterniflora and Sarcocornia perennis (Perillo \& Piccolo 1999). The images used corresponded to different dates showing varying levels of tidal inundation (15 January $1999=0.19 \mathrm{~m}, 7$ July $1998=0.47 \mathrm{~m}$, 28 January $1998=1.57,16$ February $1999=2.55 \mathrm{~m}$, 28 November $1998=3.07 \mathrm{~m}, 2$ April $1998=3.97$, 27 October $1998=4.4 \mathrm{~m}$ ) and were processed with ERDAS IMAGINE software. For comparative purposes, images were geometrically corrected and referenced to the Mercator projection. Using an ISODATA algorithm, an unsupervised classification was performed on the image with the highest tide (i.e. 27 October 1998), with a maximum of 200 possible classes and $98 \%$ of unchanged pixels between iterations for the convergence of the algorithm. The spectral signatures for the obtained original set of classes allowed us to distinguish 5 principal groups: water, marsh, coastal land, salt deserts, and inland. The classification map was recoded to unify the 3 classes belonging to areas that were never covered by water (coastal land, salt deserts, and inland) resulting in a final map with 3 defined areas: water, intertidal, and land zones. The same classification was performed on each of the other images using the same parameters. The class 'land' of the image from 27 October 1998 was used to mask the surface always occupied by land in each map. The class 'water' was defined by analyzing the spectral signatures of the different classes in each map, and the remaining classes were assigned to the 'intertidal' class. The area covered by water and the intertidal zone in each map was estimated in hectares.

The spatial distribution and the density of burrows across the intertidal slope of the Bahía Blanca estuary were evaluated by placing $1 \mathrm{~m}^{2}$ square frames at $10 \mathrm{~m}$ intervals across 20 transects. These transects were perpendicular to the shoreline and extended from the mean low tide level to the mid high tide level. The number of burrows, the proportion of burrows showing funnel-shaped entrances, the diameter and depth of these entrances, and the proportion of the area covered by plants within each square was recorded. The sampling units were then assigned to the strata delimited by the successive values of tidal elevation corresponding to the satellite maps (i.e. 0.19-0.47, $0.47-1.57,1.57-2.55,2.55-3.07,3.07-3.97$, and $3.97-$ $4.40 \mathrm{~m}$ above mean low tide level). The density and proportion of burrows showing funnel shaped entrances was estimated for each of these strata.

\section{RESULTS}

Most burrows showed a low aspect ratio (funnel depth/entrance diameter $<1$; Fig. 1) and the depth of the funnel was significantly correlated with the entrance diameter $\left(\mathrm{r}^{2}=0.57, \mathrm{n}=75, \mathrm{p}<0.05\right)$.

The amount of material transported as bedload varied between 20 and $2400 \mathrm{~g} \mathrm{~m}^{-1}$ tidal cycle ${ }^{-1}$ (Fig. 2a). The field experiments indicated that the amount of material trapped by burrow mimics differed among sampling dates. Differences in dry weight of trapped material among burrow mimics of different architecture were found during 6 of the 15 tidal cycles evaluated (Table 1, Fig. 2b). In all cases, a significantly higher dry weight of material was collected in the large aspect ratio mimics relative to the other mimics (Fig. 2b). On the other hand, the amount of organic matter (as percentage of AFDW) trapped in large aspect ratio funnel-shaped mimics was lower than that collected in mimics with a higher aspect ratio in 8 of the 15 tidal cycles evaluated (Table 1, Fig. 2c). Signifi-

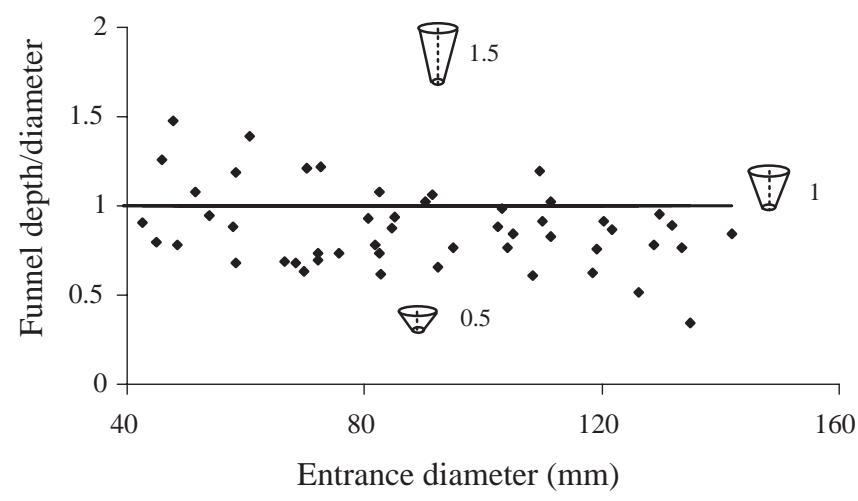

Fig. 1. Relationship between funnel aspect ratio (funnel depth/ entrance diameter) and entrance diameter of Chasmagnathus granulatus burrows. Horizontal line indicates a ratio of 1 
cant correlation was found between percentage of AFDW and percentage of macrodetritus in the sediments collected in mimics $\left(\mathrm{p}<0.05, \mathrm{r}^{2}=0.76\right)$.

Crab beds were always characterized by sediments with a significantly higher content of silt and clay than adjacent areas without crabs (Smirnov-test results: 0 to $5 \mathrm{~cm}$ depth: $D=0.39 ; 5$ to $10 \mathrm{~cm}$ depth: $D=0.35 ; 10$ to 15 cm depth: $D=0.33$; p $<0.05$ in all cases; Fig. 3). At all depth layers, water content in areas with crabs was higher than outside crab beds ( $t$-test results: 0 to $5 \mathrm{~cm}$ depth: $t=5.1 ; 5$ to $10 \mathrm{~cm}$ depth: $t=5.6 ; 10$ to $15 \mathrm{~cm}$ depth: $t=8.7 ; \mathrm{df}=8 ; \mathrm{p}<0.05$ in all cases; Fig. 3). The percentage of AFDW was not different between areas with and without crabs in the superficial layer $(t=0.3$, $\mathrm{df}=12 ; \mathrm{p}>0.05 ;$ Fig. 3), but was higher inside crab beds in the other layers ( 5 to $10 \mathrm{~cm}$ depth: $t=2.32 ; 10$ to $15 \mathrm{~cm}$ depth: $\mathrm{t}=5.12 ; \mathrm{df}=12, \mathrm{p}<0.05$ in both cases; Fig. 3).

Values of $\delta^{13} \mathrm{C}$ in Spartina densiflora ranged between -13 and $-13.2 \%(x=-13.06$; $\mathrm{SD}=0.1, \mathrm{n}=5)$; significantly differing from the values obtained for macroalgae $(x=-17.5 ; \mathrm{SD}=0.6, \mathrm{n}=5)$, or microalgae
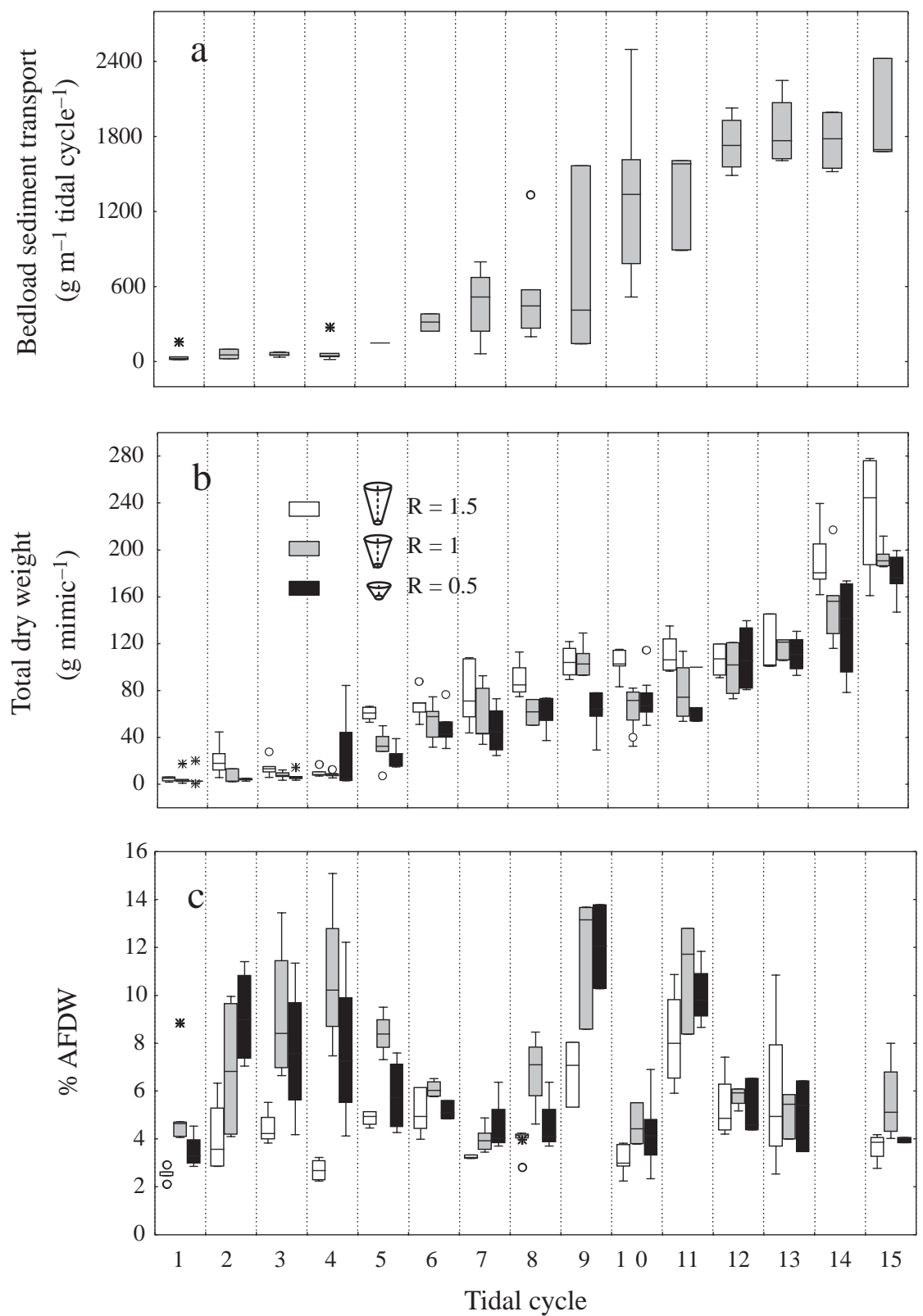

Fig. 2. (a) Rates of bedload sediment transport (estimated from cylindrical traps) during 15 tidal cycles. (b) Dry weight of sediments $\left(\mathrm{g} \mathrm{mimic}^{-1}\right.$ ) and (c) \% ash free dry weight (AFDW) in the sediments trapped in burrow mimics of different aspect ratio (R). Box plots: boxes represent 75th and 25th percentiles; lines outside boxes represent 10th and 90th percentiles; lines inside boxes are medians, $\mathrm{o}$ and $*$ represent outliers 
Table 1. Results of the Kruskal-Wallis test for each tidal cycle, evaluating differences in total weight and ash free dry weight (AFDW) of trapped sediment among Chasmagnathus granulatus burrow shapes. Significant at ${ }^{*} p<0.05$ or ${ }^{* *} p<0.01$. na: not available

\begin{tabular}{|cllcc|}
\hline \multirow{2}{*}{ Tidal } & \multicolumn{5}{c}{ Kycle } & \multicolumn{5}{c}{ Total weight } & \multirow{2}{*}{ AFDal-Wallis } \\
\cline { 2 - 5 } \cline { 3 - 4 } & $H_{(2,14)}$ & $\mathrm{p}$ & $H_{(2,14)}$ & $\mathrm{p}$ \\
\hline 1 & 0.59 & 0.7 & 10.1 & $<0.01^{* *}$ \\
2 & 8.27 & $0.01^{*}$ & 5.9 & $0.04^{*}$ \\
3 & 4.2 & 0.1 & 6.0 & $0.04^{*}$ \\
4 & 2.28 & 0.3 & 8.0 & $0.02^{*}$ \\
5 & 9.9 & $<0.01^{* *}$ & 6.7 & $0.03^{*}$ \\
6 & 2.7 & 0.3 & 4.2 & $0.1^{*}$ \\
7 & 2.8 & 0.2 & 6.5 & $0.03^{*}$ \\
8 & 8.65 & $0.01^{*}$ & 4.6 & 0.09 \\
9 & 7.05 & $0.03^{*}$ & 7.19 & $0.03^{*}$ \\
10 & 2.8 & 0.2 & 4.7 & 0.09 \\
11 & 7.75 & $0.02^{*}$ & 7.28 & $0.03^{*}$ \\
12 & 1.9 & 0.5 & 0.58 & 0.7 \\
13 & 1.02 & 0.5 & 0.16 & 0.9 \\
14 & 6.02 & $0.04^{*}$ & na & na \\
15 & 3.24 & 0.2 & 4.7 & 0.09 \\
\hline
\end{tabular}

$(x=-16.28 ; \mathrm{SD}=0.38, \mathrm{n}=5 ;$ ANOVA: $F=146.1 ; \mathrm{df}=2$, $12 \mathrm{p}<0.05) \cdot \delta^{13} \mathrm{C}$ values of surface sediments were not different between the surface layer $(x=-11.5$; $\mathrm{SD}=0.6$, $\mathrm{n}=5$ ) and those of the sediments found at funnelshaped burrow entrances $(x=-10.8 ; \mathrm{SD}=1.3, \mathrm{n}=5$; $t=0.95 ; \mathrm{p}>0.05)$. These values showed enrichment in ${ }^{13} \mathrm{C}$ indicating a higher component of $\mathrm{C}$ derived from $S$. densiflora than from algae. The values obtained from crabs $(x=-12.6 ; \mathrm{SD}=0.7, \mathrm{n}=5)$ were as expected

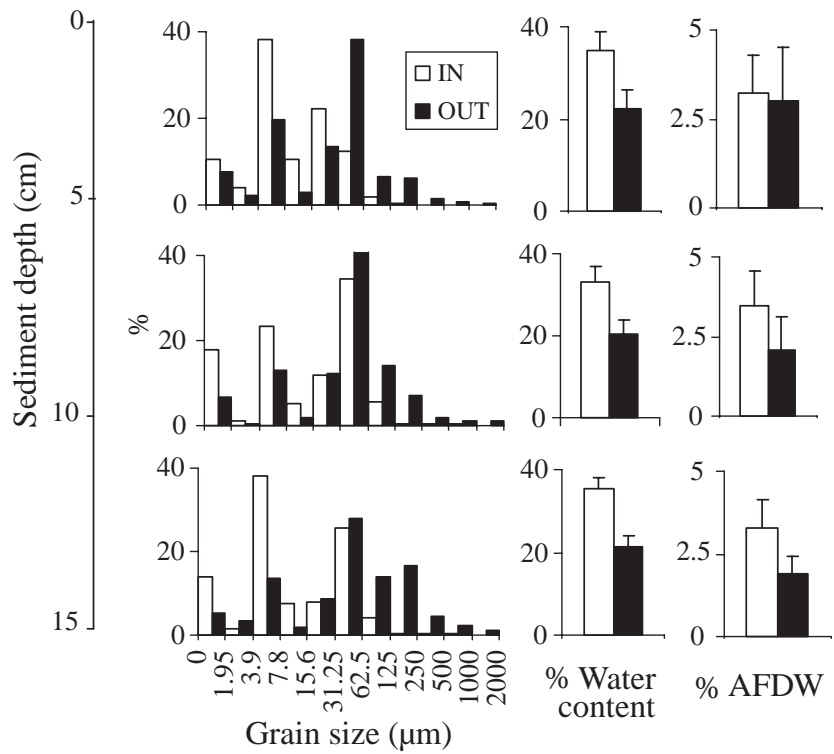

Fig. 3. Sediment grain size, water content, and organic matter content of sediment at 3 depth layers inside (IN) and outside (OUT) Chasmagnathus granulatus beds

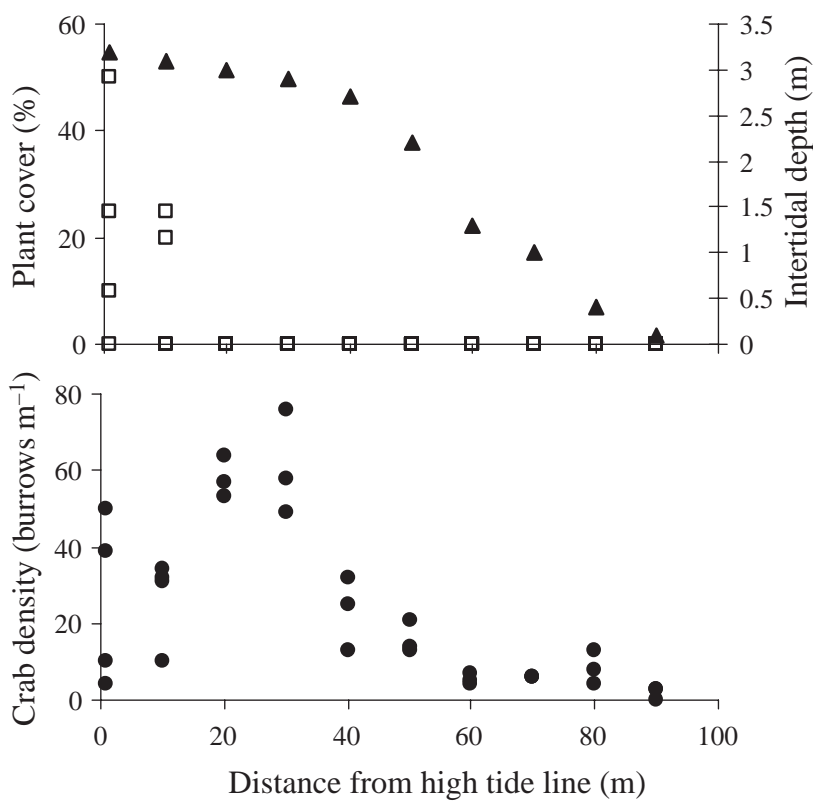

Fig. 4. Intertidal depth ( $\mathbf{\Lambda})$, percentage of plant cover ( $\square$ ), and Chasmagnathus granulatus density $(\bullet)$ at different distances from the mean high tide level

from the enrichment in terms of ${ }^{13} \mathrm{C}(1 \%)$ and with $S$. densiflora as a main food source (either as detritus or living plants).

Crabs were found everywhere at the interface between the salt marsh and the subtidal area. Sampling across the intertidal slope showed that the highest burrow densities occurred $1 \mathrm{~m}$ below the highest tidal level

Table 2. Surface area estimated from satellite images corresponding to the range of the different tidal elevations, percentage of Chasmagnathus granulatus burrows with a funnel shape, density of funnel shape burrows (mean $\pm \mathrm{SD}$ ), and amount of organic matter trapped $\mathrm{d}^{-1}$ (mean $\pm \mathrm{SD}$ ) in each strata relative to mean weight of organic matter trapped in experiments $\left(3.1 \mathrm{~g}\right.$ burrow $\left.{ }^{-1} \mathrm{~d}^{-1}\right)$

\begin{tabular}{|lcccc}
\hline $\begin{array}{l}\text { Tidal } \\
\text { elevation } \\
(\mathrm{m})\end{array}$ & $\begin{array}{c}\text { Area } \\
(\mathrm{ha})\end{array}$ & $\begin{array}{c}\text { Burrows } \\
\left(\mathrm{m}^{-2}\right)\end{array}$ & $\begin{array}{c}\% \\
\text { funnel } \\
\text { shape }\end{array}$ & $\begin{array}{c}\text { Trapped } \\
\text { organic matter } \\
\left(\mathrm{g} \mathrm{m}^{-2} \mathrm{~d}^{-1}\right)\end{array}$ \\
\hline 4.4 & 1036 & $40.6 \pm 3.5$ & 32 & $40.27 \pm 10.88$ \\
3.98 & 2279 & $19.7 \pm 0.2$ & 55 & $33.5 \pm 6.72$ \\
3.07 & 569 & $5.3 \pm 0.7$ & 85 & $14.05 \pm 2.03$ \\
2.55 & 806 & $7.1 \pm 1.5$ & 100 & $22.2 \pm 0.90$ \\
1.57 & 295 & $2 \pm 0.8$ & 100 & $6.2 \pm 2.72$ \\
0.47 & 140 & $0.2 \pm 0.1$ & 100 & $0.41 \pm 0.39$ \\
0.19 & & & & \\
\hline
\end{tabular}


immediately surrounding the vegetated area (Fig. 4). The extent of the total intertidal area covered by the satellite images was 5949 ha. The extent of each of the strata delimited by successive values of tidal elevation corresponding to the satellite images is presented in Table 2. The smallest proportion of funnel-shaped burrows $(32 \%)$ was observed in the upper strata (i.e. 3.97 to $4.40 \mathrm{~m}$ above mean low tide level); at the lowest tidal levels (i.e. 0.19 to $2.55 \mathrm{~m}$ above mean low tide level; see Table 2), $100 \%$ of burrows were funnel shaped.

\section{DISCUSSION}

Burrowing species are common in benthic subtidal and intertidal soft sediments (Aller \& Dodge 1974, Peterson 1977, 1979), with many species like thalassinidean shrimps (Bird 1982, Murphy 1985, Posey 1986, 1990, Weitkamp 1991) or crabs (Iribarne et al. 1997, Botto \& Iribarne 2000) constructing extensive galleries. These species dominate by number and/or ecological effect in many temperate estuaries worldwide (e.g. west of North America, southeastern USA, South Africa, Australia, and New Zealand) including the southwestern Atlantic estuaries, which are dominated by the burrowing crab Chasmagnathus granulatus. This species usually plays a key role in determining community structure in estuarine tidal flats (Botto \& Iribarne 1999). It directly affects nematods, polychaetes, juvenile crabs (Botto \& Iribarne 2000), the cordgrass Spartina densiflora (Bortolus \& Iribarne 1999), and the fiddler crab Uca uruguayensis (Daleo et al. 2003), or indirectly affects shorebirds (Botto et al. 1998, 2000, Palomo et al. 2003) and polychaetes (Escapa et al. 2004). However, most of its effects on the distribution and abundance of other species are not trophic but the consequence of environmental modification and subsequent changes in resource levels (i.e. 'ecosystem engineering'; sensu Jones et al. 1994).

Engineering effects of Chasmagnathus granulatus can go well beyond the realm of local community structure. Burrows also affect geochemistry and oxygenation of sediments (see Ziebis et al. 1994) and distribution of particles (see Watling 1991, Botto \& Iribarne 2000), therefore affecting food availability for C. granulatus and other organisms. Moreover, in this study we demonstrated that burrows of C. granulatus affect local sediment properties and act as passive traps of organic matter. This may have important implications for the functioning of estuarine ecosystems. Considering that C. granulatus burrows occur at the interface between salt marshes and open estuarine waters, we should expect that they intercept the fluxes of organic matter and nutrients between these 2 environments.
The funnel-shaped burrows of Chasmagnathus granulatus with low aspect ratio (depth/diameter $<1$ ) exemplify a common entrance shape among burrowing species, and have been suggested to work as a sediment trap in other thalassinidean shrimps (Suchanek 1983, Poore \& Suchanek 1988, Witbaard \& Duineveld 1989, Vaugelas 1990, Nickell \& Atkinson 1995). Our results confirm that these burrows are efficient bedload collectors. As evaluated in other depressions, burrows of $C$. granulatus enhance the deposition of suspended and bedload materials. Burrows always trap sediment and organic matter, but funnel shaped burrows with low aspect ratio (depth-width ratio $\leq 1$ ) were found to trap higher percentage of organic matter while more tubular burrows (depth-width ratio $>1$ ) trapped a greater proportion of sediment.

Our results show that the funnel-type burrows are actually over-collectors (sensu Butman 1986), producing turbulence in surface water and trapping suspended particles. In contrast, more tubular burrows capture only the bedload. It is also well known that the collection efficiency of conical pits can be affected by turbulence, which decreases the residence time of particles in the pits (Yager et al. 1993). While this argument could also apply to the funnel-shaped entrances of Chasmagnathus granulatus burrows, it must be noted that particles trapped in burrow funnels may also decant into the burrow tunnel where the probability of particle resuspension is presumably lower. Moreover, roughness elements made by crabs (such as the sediment mounds they produce during burrow maintenance and feeding) could also enhance the deposition of material to burrows (see Yager et al. 1993). Here, we have also found (1) that the funnel entrance of most C. granulatus burrows show aspect ratio values equal or less than 1, and (2) that funnel shaped burrows with low aspect ratio values $(\leq 1)$ are more efficient traps for organic matter than burrows with higher aspect ratio $(>1)$. All this evidence suggests that $C$. granulatus burrows have an adaptative architecture that maximizes the collection of organic particles that may serve as food for this species.

The values of stable isotopes in Spartina densiflora were similar to other Spartina species that are highly enriched in ${ }^{13} \mathrm{C}$ (Sullivan \& Montcreiff 1990, Currin et al. 1995, Botto et al. 2005), which is characteristic of plants with $\mathrm{C}_{4}$ metabolism. Sediments collected from the mudflat surface and the funnel-shaped burrow entrances showed ${ }^{13} \mathrm{C}$ values similar to $S$. densiflora and dissimilar to algae. These results suggest that the organic matter available at the sediment surface or inside burrows predominantly originated in the marsh. Isotopic values of Chasmagnathus granulatus also indicated that the organic matter that these crabs consume is primarily derived from $S$. densiflora. 
Our experiments demonstrated that burrows can incorporate up to $51 \mathrm{~g} \mathrm{~m}^{-2}$ tidal cycle ${ }^{-1}$ (see Table 2) of organic matter (OM) into the sediment in areas of highest crab densities, markedly enriching the crab bed sediments. Recognized input of OM from organisms into sediments includes mucus secretion (Riemann \& Schrage 1983, Klause 1986), production of metabolic wastes (Smallwood et al. 1999), application of organic coatings on burrow walls (Aller 1983, Watling 1991), and the increase of microbial activity (Watling 1991). However, the enhancement of nutrients in sediments due to increased deposition of detritus has not received much attention (Palmer et al. 2000, but see Smallwood et al. 1999). This process, however, seems important in SW Atlantic estuaries dominated by burrowing crabs. Sediments from crab beds are generally richer in organic matter than nearby areas without crabs (Botto \& Iribarne 2000, Escapa et al. 2004, this study), which is likely a consequence of the trapping of organic matter within crab burrows. Moreover, the density and body condition of deposit feeding species such as polychaetes is usually greater in crab beds (Palomo et al. 2003), likely due to better nutritional value of sediment in these areas.

The trapping of organic matter in burrows and its incorporation into intertidal sediments may have critical consequences for nutrient mass balance at the whole estuary scale. Burrow beds are distributed between marshes and the open estuary (see Spivak et al. 1994, Iribarne et al.1997, this study), which implies that they can intercept the fluxes of particulate matter between these 2 environments. The stable isotope signatures of tidal flat sediments indicated that there is a flux of detritus from marshes to lower elevations in the tidal slope. However, the amount of organic matter trapped in burrows suggested that these detritus fluxes were unlikely to extend beyond intertidal crab beds. Considering the density of funnel-shaped burrows at different intertidal heights (i.e. excluding all the burrows showing aspect ratio $>1$ ), and assuming a rate of organic matter collection of $0.84 \mathrm{~g}_{\text {burrow }}^{-1} \mathrm{~d}^{-1}$ (the minimum amount trapped by a burrow mimic), the amount of detritus trapped in the area of the Bahia Blanca estuary covered by the satellite image (i.e. $5949 \mathrm{ha}$ ) would be $306934 \mathrm{~kg} \mathrm{~d}^{-1}$. Assuming a net aerial primary production of $2.8 \mathrm{~kg}$ (dry weight) $\mathrm{m}^{-2} \mathrm{yr}^{-1}$ (i.e. the maximum estimated for Spartina salt marshes; Schubauer \& Hopkinson 1984, Day et al. 1989) for the marshes at the Bahía Blanca estuary, we can conclude that these burrowed tidal flats can trap an amount of detritus equivalent to the annual production of an equally sized Spartina marsh in less than 100 d. This time period could be an overestimate; marsh productivity can be as low as $0.4 \mathrm{~kg}$ (dry weight) $\mathrm{m}^{-2} \mathrm{yr}^{-1}$ (Valiela et al. 1976) and funnel-shaped burrows can trap up to $7.4 \mathrm{~g} \mathrm{~d}^{-1}$ of organic matter. Moreover, burrow types other than those with funnel-shaped entrances constitute a substantial proportion of the total burrows in the mudflat, and could further contribute to detritus trapping. In conclusion, our results strongly suggested that the extensive SW Atlantic intertidal areas inhabited by the burrowing crab Chasmagnathus granulatus work as large macro-detritus retention areas, reducing the amount of organic matter that can be exported from marshes to the open estuary. Any other burrowing species that maintain permanently open burrows in estuarine tidal flats may have similar ecological impacts on the intertidal environment.

Acknowledgements. We thank M. Teichberg for her comments on the manuscript. This research was supported by grants from the Universidad Nacional de Mar del Plata, CONICET (PIA No. 6097 to O.I.), International Foundation for Science, Sweden (No. A/3058-2F to F.B.), Agencia Nacional de Promocion Cientifica y Tecnologica (PICT 13527-03 to O.I.), and Fundación Antorchas (No. 13956-46 to F.B., No. 53900-13 to O.I.). The Argentinean National Commission of Space Activities (CONAE) provided satellite images. F.B. and J.G. were supported by CONICET scholarships and summer research fellowships from the Woods Hole Marine Biological Laboratory.

\section{LITERATURE CITED}

Aller RC (1983) The importance of the diffusive permeability of animal burrow linings in determining marine sediment chemistry. J Mar Res 41:299-322

Aller RC, Aller JY (1986) Evidence for localized enhancement of biological activity associated with tube and burrow structures in deep sea sediments at the HEBBLE site Western North Atlantic. Deep-Sea Res 33:755-790

Aller RC, Dodge RE (1974) Animal-sediment relations in a tropical lagoon Discovery Bay, Jamaica. J Mar Res 32: 209-232

Bird EW (1982) Population dynamics of the thalassinidean shrimps and their community effects through sediment modification. PhD dissertation, University of Maryland

Bortolus A, Iribarne O (1999) Effects of the SW Atlantic burrowing crab Chasmagnathus granulata on a Spartina salt marsh. Mar Ecol Prog Ser 178:78-88

Bortolus A, Schwindt E, Iribarne O (2002) Positive plantanimal interactions of an Argentinean coastal lagoon. Ecology 83:733-742

Boschi EE (1964) Los Crustáceos Decápodos Brachyura del litoral Bonaerense (R. Argentina). Bol Inst Biol Mar (Mar del Plata) 6:1-99

Botto F, Iribarne O (1999) Effect of the burrowing crab Chasmagnathus granulata on the benthic community of a SW Atlantic coastal lagoon. J Exp Mar Biol Ecol 241:263-284

Botto F, Iribarne O (2000) Contrasting effects of two burrowing crabs (Chasmagnathus granulata and Uca uruguayensis) on sediment composition and transport in estuarine environments. Estuar Coast Shelf Sci 51:141-151

Botto F, Iribarne O, Martinez M, Delhey K, Carrete M (1998) The effect of migratory shorebirds on the benthic fauna of three SW Atlantic estuaries. Estuaries 21:700-709 
Botto F, Palomo G, Iribarne O, Martinez MM (2000) The effect of southwestern Atlantic burrowing crabs (Chasmagnathus granulatus) on habitat use and foraging activity of migratory shorebirds. Estuaries 23:208-215

Botto F, Valiela I, Iribarne O, Martinetto P, Alberti J (2005) Impact of burrowing crabs on $\mathrm{C}$ and $\mathrm{N}$ sources, control, and transformations in sediments and food webs of SW Atlantic estuaries. Mar Ecol Prog Ser 293:155-164

Butman CA (1986) Sediment traps biases in turbulent flows: results from a laboratory flume study. J Mar Res 44: 645-693

Butman CA, Grant WD, Stolzenbach KD (1986) Predictions of sediment trap biases in turbulent flows: a theoretical analysis based on observations from the literature. J Mar Res 44: 601-644

Carver RE (1971) Procedures in sedimentary petrology. Wiley Interscience, New York

Couch CA (1989) Carbon and nitrogen stable isotopes of meiobenthos and their food resources. Estuar Coast Shelf Sci 28:433-441

Currin C, Newell, S, Paerl HW (1995) The role of standing dead Spartina alterniflora and benthic microalgae in salt marsh food webs: considerations based on multiple stable isotope analysis. Mar Ecol Prog Ser 121:99-116

Day JW Jr, Hall CAS, Kemp WM, Yañez-Arancibia A (1989) Estuarine ecology. John Wiley \& Sons, New York

Deegan LA, Garrit RH (1997) Evidence for spatial variability in estuarine food webs. Mar Ecol Prog Ser 147:31-47

DePatra KD, Levin LA (1989) Evidence of the passive deposition of meiofauna into fiddler crab burrows. J Exp Mar Biol Ecol 125:173-192

Emerson CW (1991) A method for the measurement of bedload sediment transport and passive faunal transport on intertidal sandflats. Estuaries 14:361-371

Escapa M, Iribarne O, Navarro D (2004) Indirect effect of intertidal burrowing crabs on infaunal zonation patterns, tidal behavior and risk of mortality. Estuaries 27:132-146

Hemminga MA, Cattrijsse A, Wielemaker A (1996) Bedload and nearbed detritus transport in a tidal saltmarsh creek. Estuar Coast Shelf Sci 42:55-62

Iribarne O, Botto F (1998) Orientation of the extant stout razor clam Tagelus plebeius in relation to current direction: its paleoecological implication. J Shellfish Res 17:165-168

Iribarne O, Bortolus A, Botto F (1997) Between-habitat differences in burrow characteristics and trophic modes in the southwestern Atlantic burrowing crab Chasmagnathus granulatus. Mar Ecol Prog Ser 155:137-145

Jones CG, Lawton JH, Shachak M (1994) Organisms as ecosystem engineers. Oikos 69:373-386

Klause MD (1986) Mucous secretions of the acoel turbellarian Convoluta sp. Orsted: an ecological and functional approach. J Exp Mar Biol Ecol 97:123-133

Lajtha K Marshall JD (1994) Sources of variation in the stable isotopic composition of plants. In: Lajtha $\mathrm{K}$, Michener RH (eds) Stables isotopes in ecology and environmental sciences. Blackwell Scientific Publications, Oxford, p 1-21

Lanfredi NW, Balestrini CF, Mazio CA, Schmidt SA (1987) Tidal sandbanks in Mar Chiquita coastal lagoon, Argentina. J Coast Res 3:515-520

Long SP, Mason CF (1983) Saltmarsh ecology. Blackie, Glasgow

Mann KH (1972) Macrophyte production and detritus food chains in coastal waters. Mem 1st Ital Idrobiol 29(Suppl): 353-383

Michener RH, Schell DM (1994) Stable isotopes ratios as tracers in marine aquatic food webs. In: Lajtha K, Michener RH (eds) Stable isotopes in ecology and environ- mental sciences. Blackwell Scientific Publications, Oxford, p 138-157

Murphy RC (1985) Factors affecting the distribution of the introduced bivalve, Mercenaria mercenaria, in a California lagoon: the importance of bioturbation. J Mar Res 43: 673-692

Nickell LA, Atkinson RJA (1995) Functional morphology of burrows and trophic modes of three thalassinidean shrimp species, and a new approach to the classification of thalassinidean burrow morphology. Mar Ecol Prog Ser 128: 181-197

Nixon SW (1980) Between coastal marshes and coastal waters - a review of twenty years of speculation and research on the role of salt marshes and coastal waters in estuarine productivity and water chemistry. In: Hamilton P, McDonald KB (eds) Estuarine and wetland processes with emphasis on modeling. Plenum Press, New York, p 437-526

Palmer MA, Covich AP, Lake S, Biro P and 8 others (2000) Linkages between aquatic sediment biota and life above sediments as potential drivers of biodiversity and ecological processes. BioScience 50:1062-1075

Palomo G, Botto F, Navarro D, Escapa M, Iribarne O (2003) The predator-prey interaction between shorebirds and the polychaete Laeonereis acuta is modified by burrowing crabs. J Exp Mar Biol Ecol 290:211-228

Perillo GME, Piccolo MC (1999) Geomorphologic and physical characteristics of the Bahía Blanca Estuary, Argentina. In: Perillo GME, Piccolo MC, Pino Quivira M (eds) Estuaries of South America: their geomorphology and dynamics. Springer-Verlag, Berlin, p 193-216

Peterson CH (1977) Competitive organization of the soft bottom macrobenthic communities of southern California lagoon. Mar Biol 43:343-359

Peterson CH (1979) Predation, competitive exclusion, and diversity in the soft-sediment benthic communities of estuaries and lagoons. In: Livingston RJ (ed) Ecological processes in coastal and marine systems. Plenum Press, New York, p 233-264

Poore GCB, Suchanek TH (1988) Glypturus motupore, a new callianassid shrimp (Crustacea: Decapoda) from Papua New Guinea with notes on its ecology. Proc Aust Mus 40: 197-204

Posey MH (1986) Changes in a benthic community associated with dense beds of a burrowing deposit feeder, Callianassa californiensis. Mar Ecol Prog Ser 31:15-22

Posey MH (1990) Functional approaches to soft-substrate communities: how useful are they? Rev Aquat Sci 2: 343-356

Riemann F, Schrage M (1983) The mucus-trap hypothesis on feeding of aquatic nematodes and implications for biodegradation and sediment texture. Oecologia 34: 75-88

Robertson AI (1986) Leaf-burying crabs: their influence on energy flow and export from mixed mangrove forests (Rhizophora spp.) in Northeastern Australia. J Exp Mar Biol Ecol 116: 235-247

Schubauer J, Hopkinson C (1984) Above and belowground emergent macrophyte production and turnover in a coastal marsh ecosystem, Georgia. Limnol Oceanogr 29: 1052-1065

Smallwood BJ, Wolff GA, Bett BJ, Smith CR, Hoover D, Gager JD, Patience A (1999) Megafauna can control the quality of organic matter in marine sediments. Naturwissenschaften 86:320-324

Spivak E, Anger K, Luppi T, Bas C, Ismael D (1994) Distribution and habitat preferences of two grapsid crab species in 
Mar Chiquita Lagoon (Province of Buenos Aires, Argentina). Helgol Meeresunters 48:59-78

Suchanek TH (1983) Control of seagrass community and sediment distribution by Calliannassa (Crustacea, Thalassinidea) bioturbation. J Mar Res 41:281-298

Suchanek TH (1985) Thalassinid shrimp burrows: ecological significance of species-specific architecture. Proc 5th Int Coral Reef Congr, Tahiti, 5:205-210

Suchanek TH, Williams SL, Ogden JC, Hubbard DJ, Gill IP (1995) Utilization of shallow-water seagrass detritus by Caribbean deep-sea macrofauna: the $\mathrm{C}^{13}$ evidence. DeepSea Res 32:201-214

Sullivan MJ, Moncreif CA (1990) Edaphic algae are an important component of salt marsh food-webs: evidence from multiple stable isotope analyses. Mar Ecol Prog Ser 62: $149-159$

Taylor DI, Allanson BR (1995) Organic carbon fluxes between a high marsh and estuary, and the inapplicability of the Outwelling Hypothesis. Mar Ecol Prog Ser 120:263-270

Teal JM (1962) Energy flow in the salt marsh ecosystem of Georgia. Ecology 43:614-624

Twilley RR, Pozo M, Garcia VH, Rivera-Monroy VH, Bodero RZA (1997) Litter dynamics in riverine mangrove forests in the Guayas River estuary, Ecuador. Oecologia 111: $109-122$

Valiela I (2000) Marine ecological processes, 2nd edn. Springer-Verlag, New York

Valiela I, Teal JM (1979) The nitrogen budget of a salt marsh ecosystem. Nature 280:652-656

Valiela I, Teal JM, Persson NY (1976) Production and dynam-

Editorial responsibility: Kenneth $R$. Tenore (Contributing

Editor), Solomons, Maryland, USA ics of experimentally enriched salt marsh vegetation: belowground biomass. Limnol Oceanogr 21:245-252

Valiela I, Cole ML, McClelland J, Hauxwell J, Cebrian J, Joye SB (2000) Role of saltmarshes as part of coastal landscapes. In: Weinstein MP, Kreeger DA (eds) Concepts and controversies in tidal marsh ecology. Kluwer Academic, Dordrecht, p 23-38

Vaugelas JV de (1990) Ecologie des callianasses (Crustacea, Decapoda, Thalassinidea) et milieu récifal Indo-Pacifique. Conséquences du remaniement sédimentaire sur la distribution des matieres humiques, des métaux trace et des radionucléides. Mem Univ Nice, p 1-269

Watling L (1991) The sedimentary milieu and its consequences for resident organisms. Am Zool 31:789-796

Weitkamp LA (1991) Disturbance in an intertidal sandflat community: the effect of small- and large-scale natural perturbations. MS thesis, University of Washington, Seattle

Witbaard R, Duineveld GCA (1989) Some aspects of the biology and ecology of the burrowing shrimp Callianassa subterranea (Montagu) (Thalassinidea) from the southern North sea. Sarsia 74:209-219

Yager PL, Nowell ARM, Jumars PA (1993) Enhanced deposition to pits: a local food source for benthos. J Sea Res 51: 209-236

Zar JH (1999) Biostatistical analysis. Prentice-Hall, Englewood Cliffs, NJ

Ziebis W, Forster S, Huettel M, Jorgensen BB (1994) Complex burrows of the mud shrimp Callianassa truncata and their geochemical impact in the sea bed. Nature 382:619-622

Submitted: July 15, 2004; Accepted: September 8, 2005 Proofs received from author(s): March 7, 2006 